\title{
Tom Ullrich
}

\section{Working on Barricades and Boulevards: \\ Cultural Techniques of Revolution in Nineteenth-Century Paris}

\author{
Paris ... is Paris only in ripping out its cobblestones. \\ Louis Aragon, Plus belles que les larmes (1942)
}

The rules of procedure reflect the state of the art. In making a statement about cultural techniques, there is thus no need to speculate about whether or not these instructions have been followed. The fact that they exist points to a certain practice.

Cornelia Vismann, Kulturtechniken und Souveränität (2010)

\section{The Work of Revolution}

This essay takes up the question of how revolutions were made in Paris and what can be known about them by visiting the revolution at its construction sites. ${ }^{1}$ The invested work might have to do with the construction of a barricade, a building, or a boulevard, or with a hoe and a cobblestone, or with pen and paper. And it requires us to take a closer look at the connection between mediality and processuality in this kind of revolutionary activity. My topic is thus the revolution under construction, radical change in its making - which is especially suitable for investigation by the approach offered by research into cultural techniques.

What is to be done in times of revolution? What or who is at work? Reporting on the revolutionary conditions, the republican conspirator and wine merchant Marc Caussidière writes in his memoirs about the construction of barricades in Paris that took place in February 1848:

The insurgent work went ahead with an extraordinary activity, in silence, and without any military force intervening to oppose it. Paris was a barricade construction site from the Boulevard de Gand to the Bastille, from the Porte Saint-Denis to the Seine. The insurgent

1 Construction sites are revealing sites and topoi of modernity, as was shown by the Paris exhibition "The Art of The Building Site: Construction and Demolition from the 16th to the 21st Century" (November 9, 2018, to March 11, 2019). See Valérie Nègre (ed.), L'Art du chantier: Construire et démolir du 16e au 21e siècle (Paris: Cité de l’Architecture \& du Patrimoine, 2018).

Translated by Michael Thomas Taylor 
people went out on the streets with their workshop tools, before taking up arms the next day. And alas! they felled the beautiful trees of the boulevards; they tore down the gates of the monuments, the gas lanterns, the fountains, and huts, and everything that might serve to block the way of the troops. In the streets, people carried away the building materials from the construction sites: beams, stone blocks, planks, and carts. And all of this was integrated into huge cobblestone walls. ... Soon the barricades were occupied and guarded by sentries; and one could see groups of men crouched around cracking fires, melting bullets and quietly smoking their pipes at this bizarre bivouac in the middle of the big, ploughed city, so that they might plant freedom there. ${ }^{2}$

Caussidière, who became known to the public in 1848 because of his dedicated commitment as a "barricade prefect,"3 testifies to the extensive construction work on the barricades, referencing the materials, tools, skills, and persons that were involved. This is, however, also a topos that is imagined and stereotypically depicted in contemporary prints (Fig. 1). If one poses the question of material and symbolic work to and with, for and against, barricades, Caussidière's testimony and its iconographic compression makes it possible to work out three central aspects for my analysis.

First, barricades initially stand out amid the modern metropolis as unusual construction sites: the revolutionaries make use of other buildings under construction and the material, tools, and workers available there. This is followed by a highly ambivalent refashioning of the urban environment, especially of the street surfaces, that literally rips apart the old conditions to establish a new, transitory, and revolutionary culture meant to allow a flourishing of political and social change. Caussidière's use of the grand concept of "liberty" to name the objective this refashioning in combination with agricultural metaphors (plough, plant) following the practice of planting liberty trees ${ }^{4}-$ is highly relevant for research into studies of cultural techniques, for this concept of "liberty" is clearly preceded by entire operational chains of sociotechnical processes that are expected to produce, in the first place, that very liberty in the media network of revolutionary work.

Second, this not all, because the revolution must be cultivated and maintained. After the February Revolution, for instance, Caussidière quickly took over the management of the prefecture of the police and hence the responsibility for organizing the restoration of public order. He began by seeing to the repair of the

2 Marc Caussidière, Mémoires de Caussidière, ex-préfet de police et représentant du peuple (Paris: Michel Lévy frères, 1848), 47f.; my emphasis. All translations from the French are mine, with Michael Thomas Taylor.

3 Alexandre Herzen, Passé et méditation, vol. 4., ed. Daria Olivier (Lausanne: Éditions l'Age d'homme, 1981), 339.

4 See Emmanuel Fureix, "Freiheitsbaum," in Lexikon der Revolutions-Ikonographie, vol. 2, ed. Rolf Reichardt (Münster: Rhema, 2017), 940-964. 


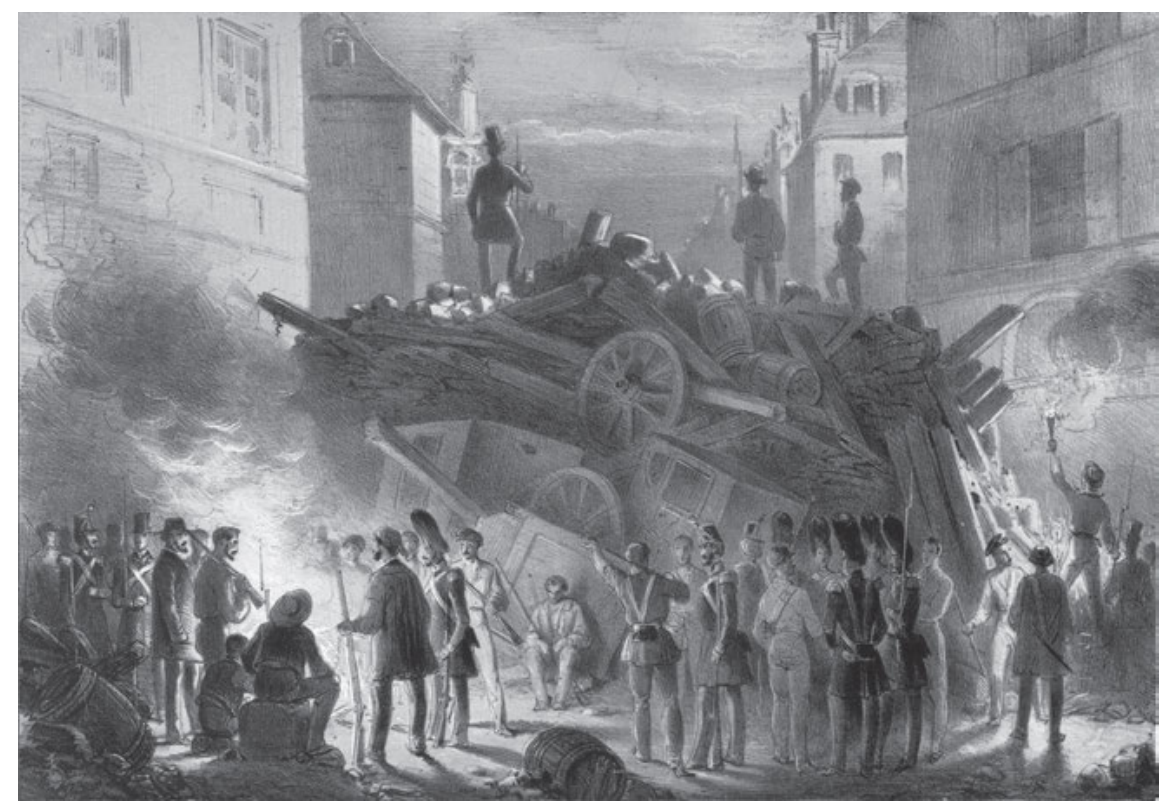

Fig. 1: Janet-Lange, Barricade de la Rue St. Martin, Paris (February 23 and 24, 1848).

road pavement torn up by the construction of the barricades. ${ }^{5}$ In doing so, the "barricade prefect" reveals an understanding of himself that marks an interesting point of tension with other postrevolutionary repair work, because this phase of restabilization and reordering following the revolutionary barricades proves to be an ideological battlefield. The debate about who is to administer the changes and consequences of a revolution (in carrying out repair work), of when and by what right, is thus quite revealing: political positions and actions are ambivalent and range from the realization of revolution to counterrevolutionary restoration, or what has been called the "Haussmannization" of Paris in the second half of the nineteenth century. ${ }^{6}$

Third, all of Paris is euphorically declared a "barricade construction site." The construction sites of the revolution, shaped by practices of improvisation, routine, or skill, quickly became the object of conspiratorial planning fantasies (as we find in the writings of Auguste Blanqui); and during the uprising of the Paris Commune in 1871, these practices took on the bureaucratic character of an

5 See Caussidière, Mémoires de Caussidière, $75 f$.

6 Clément Caraguel, "Bulletin,” in Le Charivari, January 7, 1865. 
official construction site, as if the intention had been to outdo the large construction sites of the boulevards and magnificent architectures of the Second Empire. A peculiar genealogy becomes visible here: while the communards trusted in an "aura of invincibility," they also relied upon the more recent model of an authoritarian imagination of order and disorder, as well as on the media-technical repertoire of their political opponents.

Viewing the all-too-often glorified Paris révolutionnaire ${ }^{8}$ from the perspective of media and culture studies, through an approach based in cultural techniques, allows us to go beyond previous approaches, most of which have been rooted in one discipline only. Through a case study of selected constellations of construction sites in the context of historical authoritarian urban planning, the following essay will show how engaging with the Parisian barricades of the nineteenth century can contribute to research into cultural techniques.

\section{Researching Barricades: Source Materials and Research Methods}

As one of the most curious phenomena of the nineteenth century, barricades and their (mass) media distribution were situated at the interface of multiple political, social, and industrial revolutions. Given the high frequency of revolutionary events in Paris between 1827 and $1871,{ }^{9}$ one can assume that a significantly large part of the constantly increasing urban population came into contact with barricade construction in some way, if only through acquaintances and relatives. Beyond the concrete techniques of resistance and protest, the "barricade" also left its mark linguistically and visually, which makes it all the more difficult to uncover its sociotechnical foundation apart from the metanarratives of history. The historiographic, administrative, artistic, and popular cultural knowledge of barricades that is widely available in libraries, archives, and museums proves to be both helpful and challenging. It forces us to pose hard questions from several perspectives in confronting many highly varied sources: printed sources, such as literary narratives and journal reports, conspiratorial and autobiographical writings, or military handbooks; archival documents such as parliamentary

7 Friedrich Engels, "Die revolutionäre Bewegung in Italien,” Neue Rheinische Zeitung 156, November 30 (1848): 78.

8 Godefroy Cavaignac et al., Paris révolutionnaire, 4 vols. (Paris: Guillaumin, 1833-1834).

9 There were minor uprisings or major revolutions in Paris in 1827, 1830, 1832, 1834, 1839, 1848, 1849, 1851, and 1870/1871. 
debates, police reports, court records, and files from the Paris municipal administration or national ministries; and visual representations such as paintings, prints, photographs, cartoons, and, above all, sketches, plans and maps.

The diverse references in these sources document and perform the vehemence of the controversies of the day: barricades were a favorite topic of newspaper reports; they were frequently invoked as magical objects, or fetishes (what Engels called "spells"), of revolutionary groups; ${ }^{10}$ and they were also the object of obsessive preoccupation of governments concerned with strategies to prevent and combat them.

Both quantitatively and qualitatively, barricades in the "capital of revolution"11 of the nineteenth century appeared as a ubiquitous phenomenon that we must analyze as a historically unique excess, treating, as equally important, both discursive and nondiscursive aspects of a comprehensive knowledge of the barricades.

Barricades "draw together"; ${ }^{12}$ they assemble and mediate persons, things, and signs in an extreme situation of open conflict. They contribute to the formation of a revolutionary identity and collective by offering categories for locating oneself in a political or social order. That is why they also massively demarcate and exclude, break up and keep apart, social strata, political opinions, and generations: they divide friends from foes, arranging them spatially and symbolically this side and that side of the barricade. Herein lies the ambivalent mediality of barricades as powerful media agents or milieus, which is not, however, identical with the permanent presence of the Parisian barricades that has been conveyed by (mass) media, as evidenced by the sources mentioned above. Historical and sociological research has almost completely ignored these aspects. ${ }^{13}$

Nor has there been any work on barricades in research on the history of media that investigates their discursivization and representation in the context of concrete techniques and habitualized practices. ${ }^{14}$ Research into cultural techniques allows barricades to be understood as busy spaces of assembly: they

10 Engels, "Die revolutionäre Bewegung in Italien,” 79.

11 Heinrich Heine, Über Ludwig Börne (Hamburg: Hoffmann \& Campe, 1840), 143.

12 See Bruno Latour, "Visualisation and Cognition: Drawing Things Together," Knowledge and Society: Studies in the Sociology of Culture and Present 6 (1986): 1-40.

13 Alain Corbin and Jean-Marie Mayeur (eds.), La Barricade (Paris: Publications de la Sorbonne, 1997); Mark Traugott, The Insurgent Barricade (Berkeley: University of California Press, 2010). It is striking how the barricade is understood as a simple extension of human instrumental capacities and reduced here to a singular phenomenon determined by two antithetic poles: the military and the popular, the practical and the symbolic, the organized and the spontaneous.

14 See Olaf Briese, "Moment-Architektur: Die Kunst der Barrikade und die Kunst ihrer medialen Mythisierung," in Berlin im 19. Jahrhundert: Ein Metropolen-Kompendium, ed. Roland Berbig et al. (Berlin: Akademie-Verlag, 2011), 433-447. 
create hybrid collectives and are held together only by the temporary relations of their elements. A perspective concerned with cultural techniques thus reveals those working contexts of human and nonhuman actors that, in their historically contingent network, produce something (e.g., an idea or an event) that can, in retrospect, be defamed as trouble or celebrated as révolution. In this sense, it is necessary to question the grand concepts themselves: there is no such thing as the revolution, the revolutionary, or the barricade as such independent of specific practices and techniques, of the agency of distributed labor and its intermeshing operational chains. All the same, these concepts do concern the big picture, in its entirety, as it becomes comprehensible through what is quite particular, namely, by looking at concepts and terms in light of their detailed enabling conditions and operative constitutions. The respective concrete work on the boulevards and barricades in Paris of the nineteenth century - the planned, discursive, and situatively executed acts, with their respective conflicting contexts of justification becomes particularly visible where barricades are not fully stabilized, where they are controversial or plainly under construction.

\section{Analyzing Barricades: Construction Sites of Revolution}

\section{Under Construction: Building Barricades between Conversion and Utopia (1827-1848)}

Every barricade is inextricably linked to urban space determining the material conditions under which it is produced at great effort. This ecology of the barricade influences not only the origin of its builders, their location, and the symbolic power attributed to them, but also their choice of materials. The selection of a barricade's elements depends on three properties: "their ready availability, their selective mobility and their facility for being creatively combined into an unyielding mass." ${ }^{15}$ For this reason, the barrel (barrique), from which the word "barricade" likely derives, is as iconic as it is pragmatic: it is present everywhere as medium for storage and transport, easy to roll, and filled at its destination, often with cobblestones, making it relatively stable. Seen thus, urban construction sites - with the building materials and tools they offer, which are

15 Mark Traugott, "Barricades as Material and Social Constructions,” in Disobedient Objects, ed. Catherine Flood and Gavin Grindon (London: V\&A Publishing, 2014), 26-33, here 28. 
usually stored loosely and in a way that is easily accessible - represent a location factor that is practically irresistible.

When, after a partial success in parliament against King Charles X, an exuberant celebration of several republicans on November 19, 1827, led to two-day skirmishes with the police, isolated barricades were built again for the first time since the French Revolution of 1789. Multiple officials filed independent reports of massive, almost spectacular looting of nearby construction sites. Consider, for instance, the report written by a certain Canler, head of the local Service de Sûreté:

They went down toward the Seine; when they came near the Grand-Cerf passage, they stopped in front of a building under construction, and a man with the cane cried out: To the barricades! At these words, his accomplices attacked the building, removed all the building materials and scaffolding, and a moment later, with the help of twenty clerks from the surrounding shops, had built a formidable barricade, which was immediately followed by a second. ${ }^{16}$

Cobblestones that had been set out to repair a road are stolen as well as the quarry stone that had already been polished for another residential building under construction. Some of these stones are also broken up specifically to be used as projectiles against the police. ${ }^{17}$ The statistique des barricades attached to a barricade map to memorialize the July Revolution of 1830 reports in detail on the - sometimes gruesome - extent of such material transformations of public street space in the course of the events:

One hundred and twenty-five thousand meters of cobblestone roads were used to build 4,055 barricades, not even considering those built with the trees on the boulevards, building materials from buildings, carts, furniture, and even human corpses. ${ }^{18}$

Also worth noting is an ego document by Charles Jeanne, the chief of one of the barricades built during the republican uprising of June 1832. In a letter sent from prison, Jeanne provides a detailed inside perspective on those who built the barricades, writing about their procurement management:

A building under construction on Rue Aubry-le-Boucher, near Rue St. Martin, facilitated our execution of these defensive measures; the wooden beams and crushed stones, together with the cobblestones that were continually being broken loose, were piled up with

16 Mémoires de Canler, ancien chef du service de Sûreté, vol. 1 (Paris: F. Roy, 1882), $151 \mathrm{ff}$.

17 See Annie Lauck, "Les troubles de la rue Saint-Denis ou le renouveau des barricades à Paris: Les 19 et 20 novembre 1827," in Corbin and Mayeur, La Barricade, 55-70.

18 Charles Motte, Révolution de 1830: plan figuratif des barricades (1830), Paris: Bibliothèque nationale de France, Département des cartes et plans, GE DD-5711. 
extraordinary speed: a considerable quantity of plaster, carried in baskets that we found in the building, served to fill in the gaps and thus consolidate our work. ${ }^{19}$

The numerous building sites of the barricades attract people in an almost physical way; the often-chaotic activities associated with the barricades are also directly aimed at drawing the fence-sitters and undecideds in the middle to politically and spatially take a side. Those who choose to fight for the uprising most probably do so not (only) after a reasoned consideration of the viability of a revolutionary idea, but - assuming they are not forced to do so - out of the physical-sensual attraction to the collective that is "innervated" at the barricade. ${ }^{20}$ This is because the ecology of the barricades is multisensual. It affects through cobblestones held in the hands, and through the proclamations, rhythmically repeated in the ear, of the people gathered together. The communal handling of the converted objects and tools creates an immersive barricade milieu in which, like the street, an old entrenched order is then broken up with relish and piled up to form a new revolutionary sign of life. It affects, too, through the sounds and the feeling of the nonhuman parts of this wild structure - "the din is the applause of objects," as Elias Canetti writes in Crowds and Power:

There seems to be a special need for this kind of noise at the beginning of events, when the crowd is still small and little or nothing has happened. The noise is a promise of the reinforcements the crowd hopes for, and a happy omen for deeds to come. ${ }^{21}$

It seems obvious, however, that not only things migrate from the building site to the barricade, but that the personnel, too, changes from one building site to another. This is primarily comprised of simple workers, shopkeepers, and craftsmen who occasionally became spokespersons for the revolution. ${ }^{22}$ Martin Nadaud was one such man. He came to Paris in 1830 as a fifteen-year-old seasonal worker

19 Charles Jeanne, À cinq heures nous serons tous morts! Sur la barricade Saint-Merry, 5-6 juin 1832, ed. Thomas Bouchet (Paris: Vendémiaire, 2001). In Les Misérables (1862), Victor Hugo famously produces, in a detailed description of the events of June 1832, a literary monument to such rebellious practices of radical conversion.

20 Walter Benjamin wrote in his Passagenarbeit and in his essay on the work of art of revolutions as "innervations of the collective" see W.B., Gesammelte Schriften, vol. 5, 2, 801, and Gesammelte Schriften, vol. 7, 2, 666.

21 Elias Canetti, Crowds and Power, trans. Carol Stewart (New York: Farrar, Straus, and Giroux, 1984 [1960]), 19.

22 It has often been pointed out how most of the great Paris uprisings and revolutions were made by the lower classes from a wide range of trades, even if, as in the case of July 1830 or February 1848, the bourgeoisie was able to write itself into history books and images as the actual revolutionary subject. 
from the rural region of Creuse; like many of his fellow countrymen, he then hired himself out as a stonemason. At an early age, he became involved in secret republican societies, and he received loud applause in one such meeting after the bloody uprising of June 1832, when he assured the co-conspirators present that he knew exactly where to get hammers and boards for the next opportunity to build barricades. ${ }^{23}$

Urban construction sites are thus immensely significant for the actor-network building the barricades: apart from their material dimensions, this is the case additionally, and especially, with the semantization of the barricades as a site of imagination for resistance and protest extending, in some instances, to their sociotheoretical overinterpretation as sites of utopia. For instance, the collective work on barricade construction sites first served French social theorists such as Charles Fourier (1835/36) and Joseph Déjacque (1858) as examples illustrating their social visions of egalitarian cooperation, as models of free individuals and the meaningful division of labor throughout society.

Fourier elucidates his concept of "attractive labor" by comparing it with the construction of barricades during the July Revolution of $1830 .{ }^{24}$ Déjacque even claims that barricades bring forth what is most noble in humans. He argues that barricades are the site of an ideal social situation evident, for instance, in the example of a relationship between the sexes that he sees as becoming more egalitarian and polite in times of revolution. For Déjacque, the barricade becomes a form of work that, after some "moments of passing anarchy," leads to complete harmony and a new human being. ${ }^{25}$ At the same time, for him the nonhierarchical construction and defense of barricades represents the utopian model of just labor, inasmuch as he considers this work to be a natural and entirely just result of each individual contributing to the community according to their own abilities. He exalts the barricade as an anti-authoritarian tool:

The various groups of workers are recruited voluntarily, as are the men in a barricade, and they are completely free to stay as long as they want, or to change to another group, or

23 Martin Nadaud, Mémoires de Léonard, ancien garçon maçon (Bourganeuf: A. Duboueix, 1895), 212f. When the revolution broke out in February 1848, the staunch socialist Nadaud had just become a foreman of a group of stonemasons repairing a construction site at the town hall of the twelfth arrondissement. From there, he and his colleagues quickly join the crowd that was simultaneously storming the Tuileries Garden. Afterwards, Nadaud continued his political career as a member of the French parliament.

24 Charles Fourier, La fausse industrie: Euvres complètes de Charles Fourier, vol. 8-9 (Paris: Bossange, 1835-1836), 400f.

25 Joseph Déjacque, “Die Humanisphäre, anarchische Utopie” (1858), in Utopie der Barrikaden, ed. Theo Bruns (Berlin: Karin Kramer, 1980), 151. 
to another barricade. There is neither a permanent nor a designated leader. The one who has the best knowledge or aptitude for this work naturally leads the others. Every man has a chance to take the initiative, depending on the abilities he claims. In turn, everyone expresses their opinions and listens to those of the others. Friendly agreement prevails; there is no authority. ${ }^{26}$

It is telling how much Déjacque - who took part in the Paris workers' uprising in June 1848, to then be driven into American exile in 1854 - was still willing to believe in a kind of natural and consensual organization of barricade work, while at the same time in Europe, Friedrich Engels and Auguste Blanqui were working to optimize the processes of barricade building and street fighting, confronted with the increasing number of barricade uprisings ending in defeat and an urban planning policy that was becoming increasingly repressive.

\section{Postrevolutionary Street Work: Repairing, Renovating, Restoring (1848-1870)}

In 1848, when Paris experienced two extremely violent clashes over a period of five months between workers, bourgeois, and military forces, a discourse on urban planning that had already emerged in the eighteenth century reached a point of culmination. The aim was to free the French capital from its medieval structures: "easy circulation, hygiene and safety in Paris's quarters" is what the architects and engineers Grillon, Callou, and Jacoubet demand; ${ }^{27}$ and at the same time, the journalist Henri Lecouturier publishes a "Plan for a new Paris in which revolutions will be impossible." 28

With the expanded power held from 1849 onwards by the new president, later Emperor Napoleon III, the political course was set for a fundamental transformation of the metropolis according to Saint-Simonian ideas. In response to the repeated unrest and serious sanitary deficits, a plan was drawn up by a Commission for the Beautification of Paris to manifest the new balance of governmental power in the cityscape. These priorities can be clearly read from the colored highlights of the draft: the new barracks and railway stations to be built are red, while

26 Déjacque, “Die Humanisphäre, anarchische Utopie,” 165.

27 Edme Jean Louis Grillon, G. Callou, and Théodore Jacoubet, Études d'un nouveau système d'alignements et de percements de voies publiques faites en 1840 et 1841, présentées au conseil des batimens civils, d'après l'invitation de M. le Ministre de l'Intérieur le 8 aout 1848 (1848), 28; emphasis in the original.

28 Henri Lecouturier, Paris incompatible avec la République: plan d'un nouveau Paris où les révolutions seront impossibles (Paris: Desloges, 1848). 
the wide boulevards connecting them with the city center and with each other are blue (Fig. 2). In the original and more explicit version of the accompanying report of Siméon, this was justified, among other things, by the need to ensure that the new "great streets of communication ... shorten distances and ... in case of insurrection, ensure immediate repression of attacks on public order."29

In 1853, Baron Haussmann was appointed prefect in order to quickly realize the plan. Appropriating the commission's plans, and with the full power of the state's technocratic apparatus, he set about to "provide the means to meet the needs of continually increasing circulation." 30 The politically decreed measures can be understood (following Michel Foucault) as governmental techniques intended to repair the notoriously "congested," "sick," and "unworthy" metropolis of Paris. ${ }^{31}$

In his lectures on governmentality, Foucault describes this discourse as that of "a good town plan"32 that actively factors in the openness and insecurity of modernity instead of suppressing it - specifically, "no longer that of fixing and demarcating the territory, but of allowing circulations to take place, of controlling them, sifting the good and the bad." 33 The concept of "Haussmannization" can thus be translated in the following matrix as the sum of the practices for controlling flows by sorting them:

\begin{tabular}{lll}
\hline Symptom to be fought & Object of the desired circulation & Desired effect \\
\hline Filth & Citizens and tourists & Beauty and uniformity \\
\hline Narrowness & Commerce and traffic & Speed and consumption \\
\hline Illnesses & Light and air & Health and morality \\
\hline Uprisings & Troops and cannons & Security and stability \\
\hline
\end{tabular}

29 Bibliothèque Administrative de la Ville de Paris, MS 1780, fol. 6. Cited from Casselle Pierre, "Les travaux de la Commission des embellissements de Paris en 1853," in Bibliothèque de l'École des chartes 155 (1997), 645-689, here 654.

30 Georges Eugène Haussmann, Mémoires du Baron Haussmann, vol. 2 (Paris: V. Havard, 1893), 53. 31 See Tom Ullrich, "Reparieren nach der Revolution: Kulturtechniken der Un/Ordnung auf den Pariser Straßen des 19. Jahrhunderts," in Kulturen des Reparierens: Dinge - Wissen - Praktiken, ed. Stefan Krebs, Gabriele Schabacher, and Heike Weber (Bielefeld: transcript, 2018), 373-399.

32 Michel Foucault, Security, Territory, Population: Lectures at the College De France, 1977-78, trans. Graham Burchell (New York: Palgrave Macmillan, 2009), 35.

33 Foucault, Security, Territory, Population, 93. On this process as an administration of the things of Paris and the work that Haussmannian media of bureaucracy carried out in planning the changes, see Antonia von Schöning, Die Administration der Dinge: Technik und Imagination im Paris des 19. Jahrhunderts (Zurich and Berlin: Diaphanes, 2018), 132-140. 


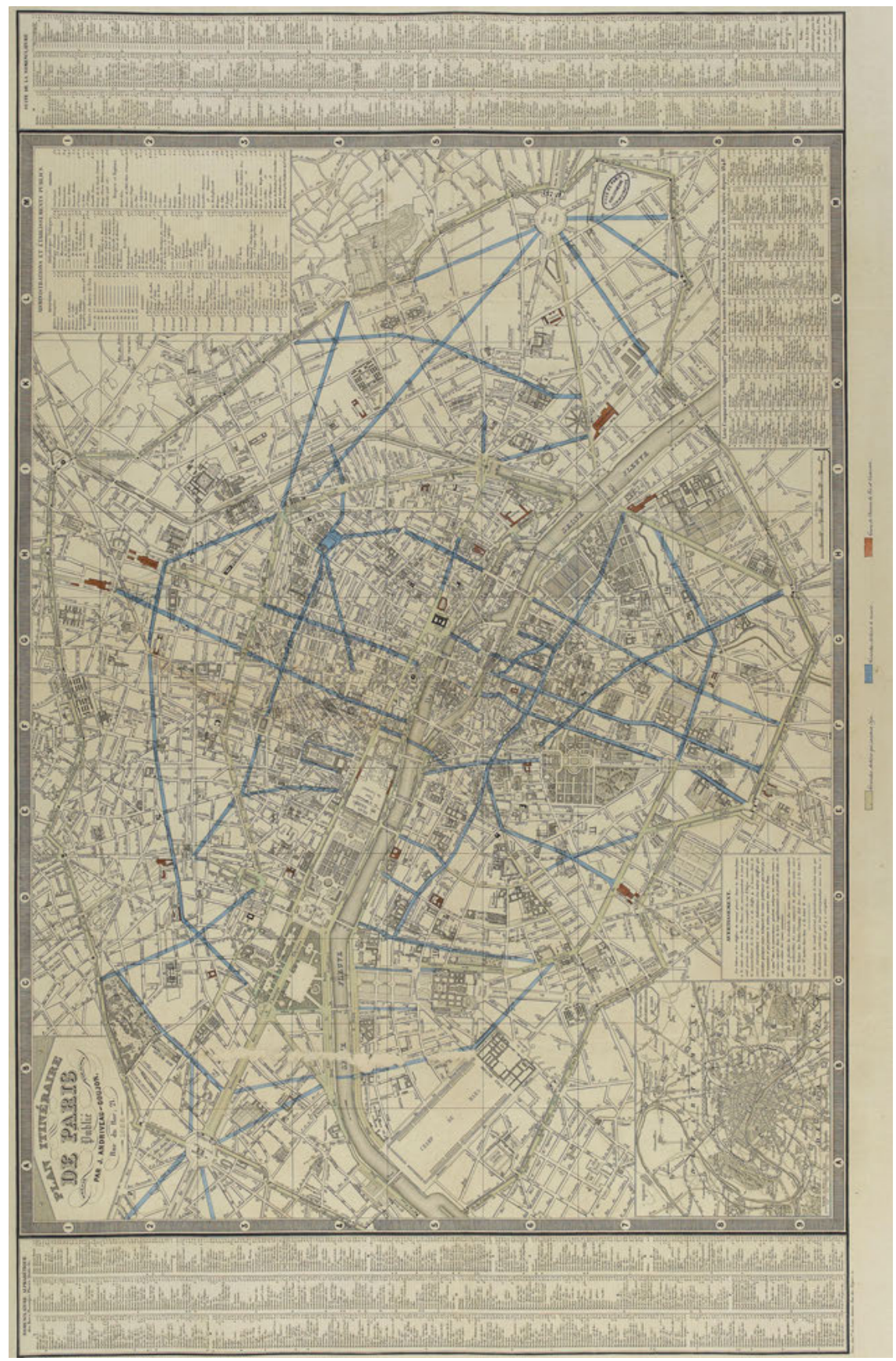

Fig. 2: Map of the Siméon Commission for the "Beautification of Paris" (1853). 
It is helpful here to consider the threat scenario, from a bourgeois perspective, of a city center inhabited by workers and craftsmen in unhygienic conditions and constant rebellion, as Haussmann again recounts much later in his memoirs (1893): his aim had been to "gut [éventrement] the old Paris, the quarter of the unrests and barricades, through a wide central road that gradually pierces this almost unusable labyrinth" and whose "entirely straight alignment is not suitable for the usual tactics of the local uprisings."34

Usually, however, the justifications for the government's goals and construction measures during the Second Empire are more implicit and less clearly separated. For example, the objectives of controlled circulation outlined above occur in alternating combinations, but always with the power to define what spreads how, and where, and to shape public urban space. In any case, this was no longer to include displeasure on the part of certain sections of the population expressed by barricading streets - an example of the power held by the idea of urban health, which, in the context of the hygienic discourse of the time, combined questions of physical well-being, morality, urban planning, and political strategy. ${ }^{35}$ To argue with Foucault: the aim of this sorting process was

ensuring that things are always in movement, constantly moving around, continually going from one point to another, but in such a way that the inherent dangers of this circulation are cancelled out. ${ }^{36}$

The security of the rulers lies in the security of the populace, whose unreliable and dissatisfied segments must be actively integrated, as Charles Merruau, Secretary General of Haussmann's Seine prefecture, announced retrospectively in 1875:

It was no longer mobs of insurgents who crossed the city, but troops of bricklayers, carpenters, and other craftsmen who rushed to the various construction sites. If the pavement was torn up, it was not to build barricades out of cobblestones, but to enable the circulation of gas and water underneath the streets. ${ }^{37}$

34 Haussmann, Mémoires, 54f.

35 See Philipp Sarasin, "Die moderne Stadt als hygienisches Projekt: Zum Konzept der 'Assanierung' der Städte im Europa des 19. Jahrhunderts,” in Stadt \& Text: Zur Ideengeschichte des Städtebaus im Spiegel theoretischer Schriften seit dem 18. Jahrhundert, ed. Vittorio Magnago Lampugnani, Katia Frey, and Eliana Perotti (Berlin: Gebr. Mann, 2011), 99-112.

36 Foucault, Security, Territory, Population, 93.

37 Charles Merruau, Souvenirs de l'hôtel de ville de Paris 1848-1852 (Paris: Plon, 1875), 496. 


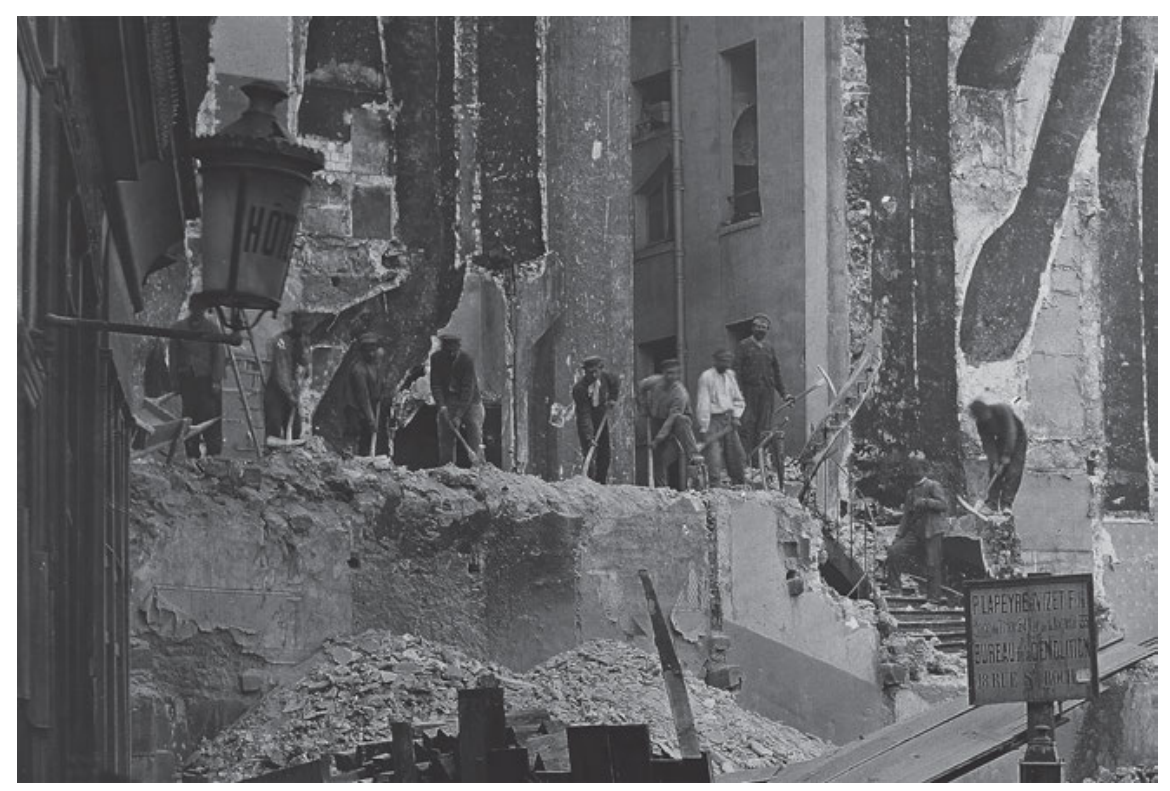

Fig. 3: Construction work to open up the Avenue de l'Opéra (1870-77) photograph by Charles Marville (excerpt).

The aim of redirecting this building activity and announcing it as a social program was not only to prevent epidemics (such as cholera in 1832 and 1849) but, in particular, to also prevent "revolution, such as the series of urban revolts." 38

The construction boom during the Second Empire, often criticized by contemporaries for its all-encompassing dimensions, also generated a mass migration of seasonal workers within France - including, not least of all, Martin Nadaud's politicized fellow citizens - that provoked a great deal of mistrust. ${ }^{39}$ Numerous caricatures (e.g., from Daumier) and photographs (e.g., from Marville) from the time depict the construction sites of the démolition as a scene full of shovels and pickaxes in action (Fig. 3). ${ }^{40} \mathrm{~A}$ revolutionary prophecy, too, can nevertheless be formulated on the basis of these tools' ambivalent use. For example, the novelist Émile Zola writes in a newspaper article from June 1868, two years before the fall

38 Michel Foucault, "Space, Knowledge, and Power," interview in The Foucault Reader, ed. Paul Rabinow (New York: Pantheon Books, 1984), 243.

39 See Casey Harison, The Stonemasons of Creuse at Nineteenth-Century Paris (Newark, DE: University of Delaware Press, 2008).

40 See Eric Fournier, Paris en ruines: Du Paris haussmannien au Paris communard (Paris: Imago, 2008). 
of Napoleon III, about the massive interventions of Haussmann's project into the cityscape of Paris:

If this prefect's army has pierced Paris in all directions, it may not want to lay down its weapons, its Homeric pickaxes that have razed half a city to the ground, and God knows what use it will make of them. ${ }^{41}$

As a matter of fact, in the spring of 1871, the government's construction sites once again turn into construction sites of revolution.

\section{Organizing the Uprising: Barricades as Professional Construction Sites (1868/1871)}

During the two-month uprising of the Paris Commune in 1871, the construction of barricades was officially institutionalized, subjecting some earlier considerations to a practical test. One exemplary early theorist of the barricade in its new guise of a professional construction site is Auguste Blanqui.

During the nineteenth century, the name Blanqui stood for the type of professional revolutionary whose concept of an overthrow through an energetic fight at the barricades, to be carried out by a small conspiratorial elite, was criticized by Marx and Engels as "project-spinning" (Projektenmacherei). ${ }^{42}$ Blanqui, who was active in secret societies at an early age, learned his lessons from Philippe Buonarroti, the author of an important book on protosocialist movements: Conspiracy for Equality (1828). In a section on "the order of the insurgent movement," the book offers a detailed discussion of the necessary sequence of measures before, during, and after an uprising; street fighting on barricades is mentioned as an emergency option. ${ }^{43}$

Having gained much practical experience, in 1868 Blanqui now builds upon this written engagement with his clandestinely circulated Instructions for an Armed Uprising. ${ }^{44}$ The text, extant today only as a manuscript, discusses the

41 Émile Zola, in La Tribune (June 21, 1868).

42 This is the pejorative description by Karl Marx and Friedrich Engels in a review in Neue Rheinische Zeitung: Politisch-ökonomische Revue 4 (April 1850): 273. See Markus Krajewski (ed.), Projektemacher: Zur Produktion von Wissen in der Vorform des Scheiterns (Berlin: Kadmos, 2008). 43 Philippe Buonarroti, Conspiration pour l'Égalité dite de Babeuf (Brussels: Librairie romantique, 1828), $192 \mathrm{ff}$.

44 See the English translation of the Instructions pour une prise d'armes in the Blanqui Archive of Kingston University: https://blanqui.kingston.ac.uk/texts/instructions-for-an-armeduprising-1868/ (visited on December 17, 2019), as well as my German translation "Auguste 
challenges of revolutionary tactics under the new urban conditions of Paris. ${ }^{45}$ The central thesis is that a successful uprising depends above all on solid planning, joint organization, and absolute discipline. There are extensive chapters devoted to constructing barricades and combat, with Blanqui sketching the ideal type of "regular barricade" and further indicating which materials, tools, and locations are suitable for barricades and how best to organize their assembly. The book calculates, for example, that for the "9,186 cobblestones" required for a barricade (three meters high, twelve meters wide), exactly forty-eight meters of a typical Parisian street would have to be stripped of its paving. ${ }^{46}$ Since Blanqui factors in the enormous time pressure during an uprising, he focuses on optimizing the insurgent operational chains: the procedural succession of the structural, organizational, and communicative acts, together with their logistical networking "with the care and in the same order as indicated above." 47

Blanqui cannot participate in the uprising of the Paris Commune because he is arrested, although his supporters form one of the many interest groups within the movement. Surprisingly, the attacked government withdrew from Paris on the first day of the uprising, March 18, 1871, leaving the barricades that had been erected as usual to the insurgents. A little-known photograph shows one of these barricades as a typical heap of stones on a street stripped of its paving, which then serves the participants not for protection, but as a stage for photo self-presentation (Fig. 4). ${ }^{48}$ The communards as well as a female cantinière pose for the camera, although on the right edge of the picture there is evidence for the work this barricade required, in two persons demonstratively holding a pickaxe and a cobblestone.

Since many communards only unwillingly comply with the request of the newly formed central committee to dismantle their barricades (the fear of a counterrevolutionary counterattack is too great, even though the revolution also depends on a suitable circulation of goods, news, and the National Guard), the construction of barricades is quickly institutionalized. As an official part of the strategy to defend the city, the construction of barricades is now assigned to a committee tasked with this purpose. In its constituent meeting of April 12, 1871,

Blanqui: Anleitung für einen bewaffneten Aufstand,” Zeitschrift für Medien- und Kulturforschung 8, 1 (2017): 85-107.

45 See Tom Ullrich, "Kommentar zu Auguste Blanquis 'Anleitung für einen bewaffneten Aufstand," Zeitschrift für Medien- und Kulturforschung 8, 1 (2017): 108-120.

46 Blanqui, Instructions for an Armed Uprising.

47 Blanqui, Instructions for an Armed Uprising.

48 See Jeannene M. Przyblyski, "Revolution at a Standstill: Photography and the Paris Commune of 1871,” in Yale French Studies 101 (2001): 54-78. 


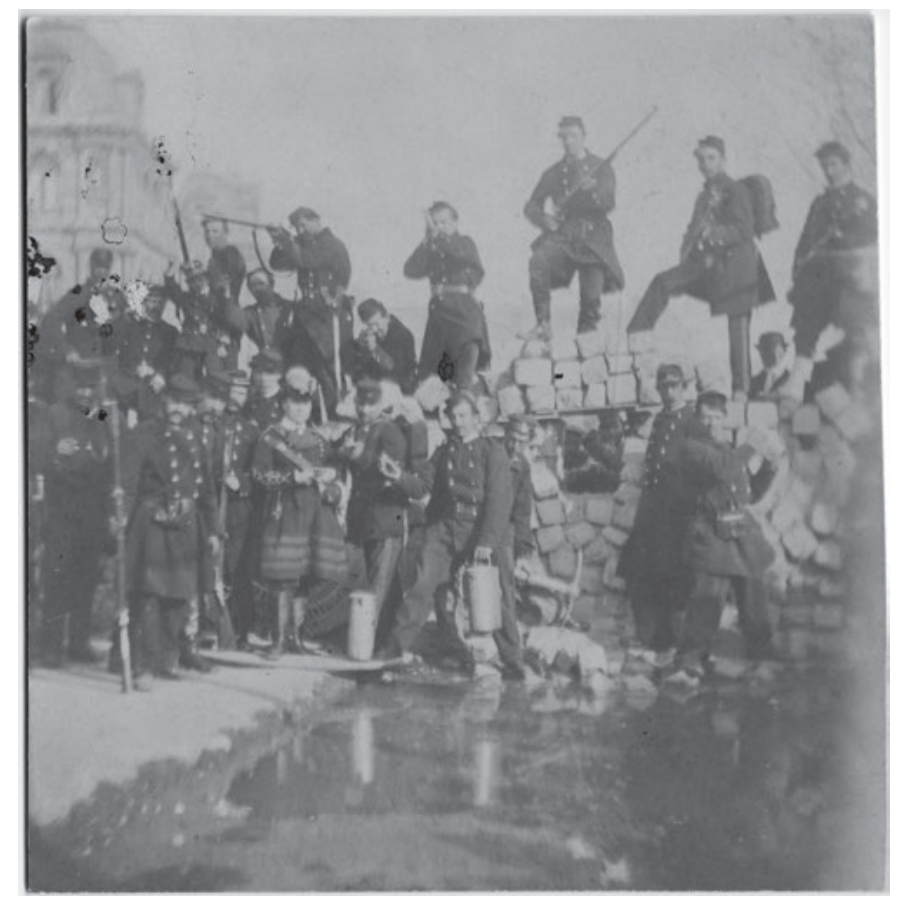

Fig. 4: Photographic staging at a barricade during the Paris Commune (March 18, 1871).

the "Barricades Commission" defines responsibilities, plans, and standard measures to guide the systematic erection of defensive structures for the resistance throughout Paris.

Gaillard Père, a shoemaker who had achieved local fame as a speaker in socialist clubs, is appointed on April 30 as head of this extraordinary Barricades Commission. He is subsequently given command of a "battalion of barricade builders," consisting of about 800 workers and 35 officers. ${ }^{49}$ In this way, the construction of the new barricades also comes to resemble the labor conditions of large construction sites, where workers are payed and organized in shifts under the guidance of architects and engineers. Uniformed soldiers guard the finished barricades, which now reflect - with their trenches, passages, and openings for cannons - the ballistic knowledge of military fortifications that informed their construction. Especially the barricade dubbed the "Castle of Gaillard" (Château Gaillard) in the Rue de Rivoli attracts a great deal of attention. The progress of this construction site was intensively discussed and pictured in newspapers (Fig. 5).

49 Marcel Cerf, “La barricade de 1871," in Corbin and Mayeur, La Barricade, 323-335. 


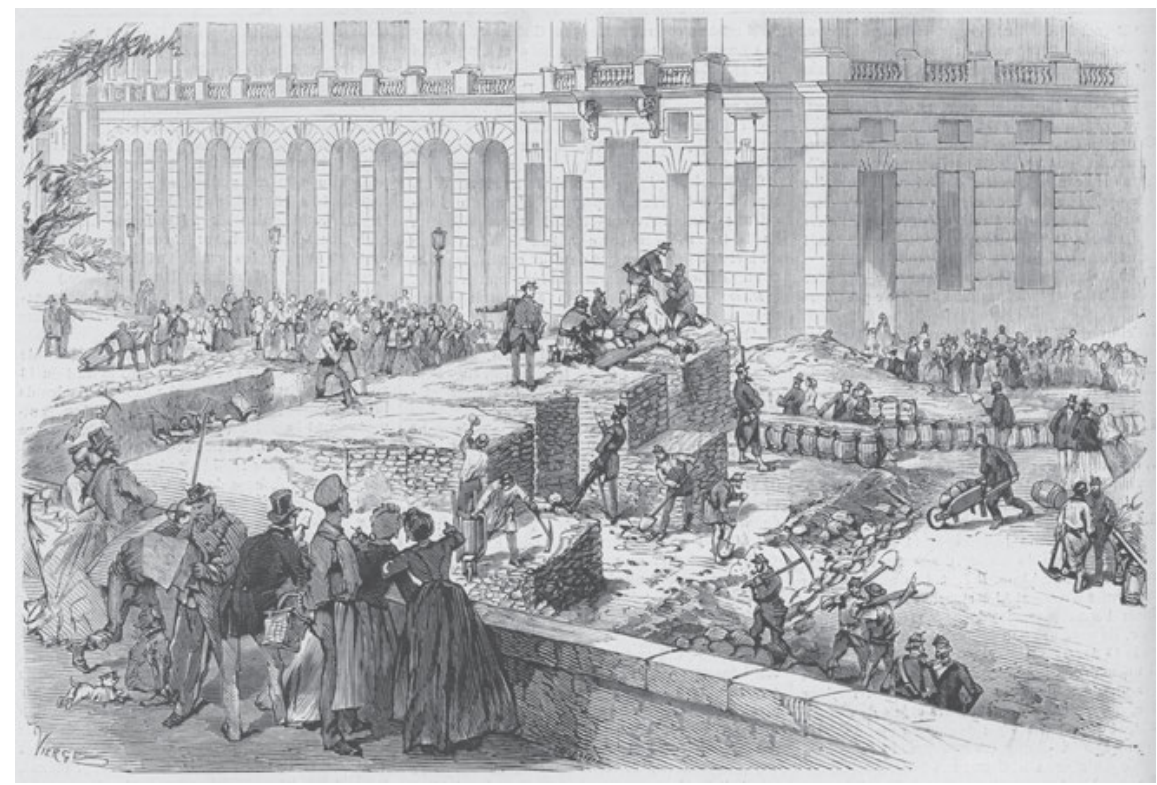

Fig. 5: Print depicting the construction work on the Château Gaillard by Vierge, in Le Monde illustré (April 29, 1871), with a focus on shovels and pickaxes as well as curious onlookers from the bourgeoisie.

Here, there is an insistence on the term "barricade" in its functions for offensive mobilization and collective psychology. At the same time, a maximum contrast emerges to all barricade construction sites that this essay has previously examined: first, to the disorderly cobblestone heaps from March 18, 1871; and second, to the utopian idea of collective labor that is found in the writings Déjacque and Fourier (which was not at all based on financial compensation). Moreover, the care with which the construction is carried out (because the leading protagonists of the Barricades Commission believe they had sufficient time, materials, and labor) and, last but not least, the narcissistic ambition of Gaillard Père, produce a kind of activity at the construction site that is completely different from what we find in Blanqui's instructions.

Gaillard Père's untimely overzealousness and boundless overestimation of himself - all of the structures he built were bypassed or captured without a fight by the troops in the bloody battles for Paris at the end of May 1871 - gave his contemporaries plenty of reasons to ridicule him. Yet for the question about the ambivalence of barricade construction sites that I have articulated here in terms of cultural techniques, this case is extremely telling. Gaillard Père gives himself the title of "general barricade director, commanding the battalion of barricade 
workers," which he usually employs to sign his letters, together with a specially made red stamp (Fig. 6). ${ }^{50}$

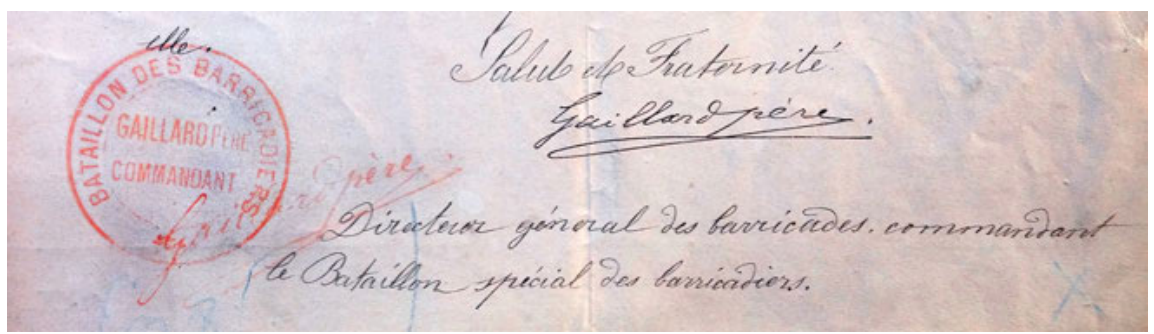

Fig. 6: Letter from Gaillard Père to the editor-in-chief of the magazine La Commune (excerpt, May, 1871): Père's signature as “directeur général des barricades, commandant le bataillon spécial des barricadiers" is visible in the letter.

Maxime du Camp, a close friend of the writer Gustave Flaubert and chronicler of Paris as a city enthralled by progress, reports on the peculiar impetus with which Gaillard Père sets up his headquarters at the Grand Hôtel du Louvre and, like an entrepreneur, establishes a bureaucratic apparatus for himself: letterhead paper with a letterhead in five variants corresponding to five different paper formats, as well a kind of blank power of attorney in the form of a preprinted letter allowing him, by virtue of his office, to confiscate all materials deemed necessary for the building of barricades. ${ }^{51}$

This constellation around the year of 1871, unique in many ways, marks the ultimate excess of the Paris barricades as a popular means of revolution that seemingly revolves only around itself. In a fatal misjudgment of its own situation, the Barricades Commission attempts to synchronize the mythical power of an outdated technology of local uprising ("action immediate, révolutionaire") with the modern idea of an industrialized order ("procédé regulier"), with the aim of defending a metropolis. The proceedings from the first meeting of the Commission April 12, 1871, reveals the entire paradox of the enterprise in a single sentence: "the barricades must be methodically studied and executed in a revolutionary way." 52

50 Raymond Huard, “Napoléon Gaillard chef barricadier de la Commune, 1815-1900," in Corbin and Mayeur, La Barricade, 311-322.

51 Maxime du Camp, Les Convulsions de Paris, vol. 2 (Paris: Hachette, 1881), 231.

52 Commission des barricades, "Séance du 12 avril 1871," in Journal officiel de la République française 103 (April 13, 1871): 237. 
At the center of this historical experiment stands the unfortunate shoemaker and barricade director Gaillard Père, who, like many other communards, loves being photographed in front of his constructions. ${ }^{53}$ His obsession with erecting particularly magnificent barricades, rather than strategically distributing as many barricades as possibly throughout the area of the uprising, comes close to that of Baron Haussmann: he also succumbs, for instance, in his very own way, to the fascination of an "administration of things" in which technology and imagination irresolvably reproduce each other. ${ }^{54}$

A few years later, the author and draftsman Albert Robida parodies these conditions in his futuristic novel Le Vingtième Siècle (The Twentieth Century, 1883), presenting the revolution, which has become a planned event taking place every ten years, as a large bourgeois folk festival in the year 1953 (Fig. 7).

In depicting a lively barricade construction site, Robida succeeds in ironically exaggerating the entire discourse on revolutionary cultural techniques of the nineteenth century as a caricature framing a page of text: in the foreground on the left, a professeur de barricades is bent over construction plans, offering "free lessons" in barricade construction; and on the right, zealous citizens are busy expanding the site with hoes, shovels, stones, and sandbags. A sign asks "passers-by" to contribute "a cobblestone" to the barricade ("un pavé en passant"). Above it, children are playing about on cannons that have already been put in place. Further up, three gentlemen study a map while others are drinking wine. The whole scene is being photographically documented by two large format cameras above and below the barricade. In the background, the facade of the house is solemnly decorated with posters, ultimately establishing the construction site of the revolution as a civic amusement park of a society of the spectacle-to-be (Guy Debord): “Vive le future gouvernement!" (Long live the future government!”)

\section{Conclusion}

During what was known as the "night of the barricade" on May 10, 1968, several of the Parisian students took possession of a construction site in Rue Gay-Lussac,

53 See Michaela Giebelhausen, "The Studio Collard and the Barricades of 1871: A Challenge Not Only to the Architecture of Paris," in Nineteenth-Century Photographs and Architecture: Documenting History, Charting Progress, and Exploring the World, ed. M.C. Nilsen (Farnham: Ashgate, 2013), 105-119.

54 Antonia von Schöning, Die Administration der Dinge. 


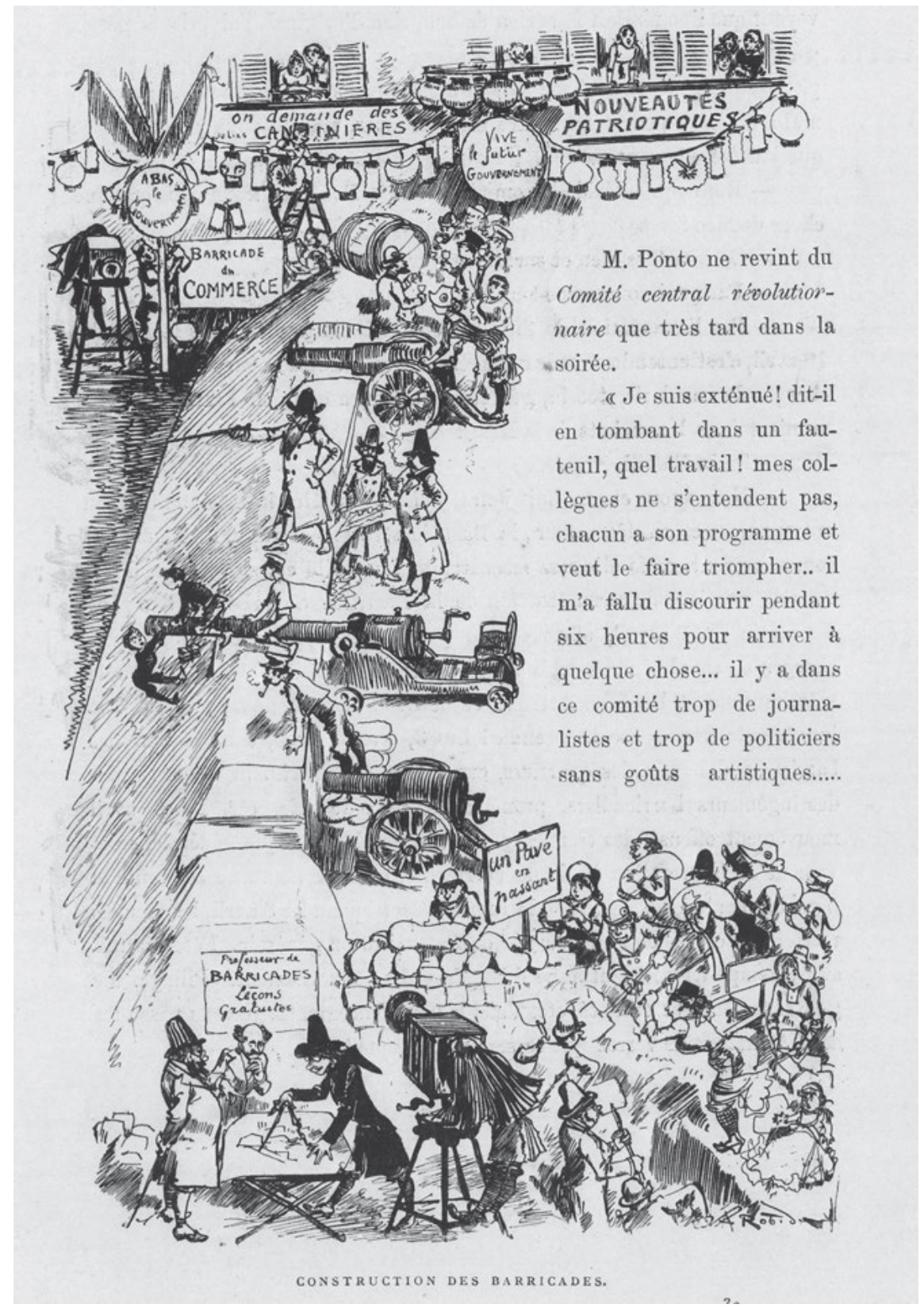

Fig. 7: "Construction des barricades," illustration, in Albert Robida, Le Vingtième Siècle (Paris: G. Decaux, 1883), 249. 
erecting dozens of barricades in the street that had been carved out a century earlier by the prefect Haussmann. In December 2018, yellow jackets protesters distinguishable, in their yellow warning vests, from the regular street workers only by the willingness some of them showed to commit violence - pile up construction site barriers and cobblestones loosened from the pavement on the Champs-Élysées in Paris - an action that spreads virally as \#barricades.

Until now, what these recent protests represent from a perspective concerned with media and cultural techniques has been explored only to a limited extent. ${ }^{55}$ Situating these events in Paris within a wider historical context not only makes it possible to better understand certain practices, for example, between protesters and the state. From the point of view of research into cultural techniques, barricade protests cannot be considered independently of the many tools, communications, and techniques of the body through which they are realized. Focusing on the materiality of the mediation work that barricades carry out allows us to break down both these historical and contemporary events into operations that go beyond individual actors and situated practices and would thus stand at odds to absolute categorizations of barricade building as a mere military tactic or revolutionary symbol.

By contrast, barricades are to be seen more as a specific constellation in which people, things, and signs are stabilized in a network of actors. In this sense, for example, the agency of a cobblestone is an extremely relevant factor, both in a planned uprising following Blanqui's instructions and for the urban planner Haussmann, who implemented new methods for paving roads. This has become clear in my essay's analysis of selected barricade construction sites and boulevards, and in the participation of human and nonhuman actors circulating between them in the period between the July Revolution of 1830 and the Paris Commune of 1871.

The results of this examination and of other work that would build on it allow us to write a different cultural history of "revolutionary Paris" - one that engages with the perspectives of mediality, processuality, and relativity, instead of repeating a "history of the barricade" that promises knowledge about immutable entities. ${ }^{56}$ Such a cultural history as media history is characterized by an exploration of the remainders and margins of all different kinds of knowledge that seeks to find stories and histories in what is impure and mixed, in the in-between and simultaneity of things that are not simultaneous. For the confrontation of archival

55 See Anna Feigenbaum, “Resistant Matters: Tents, Tear Gas and the 'Other Media' of Occupy,” Communication and Critical/Cultural Studies 11, 1 (2014): 15-24.

56 Eric Hazan's History of the Barricade (2015) is an account of the "myth of the barricade" that is rich in sources, but primarily anecdotal and theoretically lacking. 
materials shows: both in situ and in actu, it is nearly impossible to distinguish social and technical, cultural and natural, processes in revolutionary situations. No consensus was ever reached on what barricades actually do or should do, or on what they definitely represent. It is only a posteriori that, for instance, a clear differentiating operation is often claimed; this distinction is by no means naturally given but rather an effect of its specific mediality. However, the Parisian barricades are in no way impervious; they have gaps and passages that connect and keep apart. They are always being rebuilt and repaired, abandoned and removed, controlled and exaggerated, observed and presented. Barricades were and are an important laboratory of modernity, and yet they play no role in existing cultural and technological histories of the construction site. ${ }^{57}$

If neither the human being as such nor time as such exist without the cultural techniques of hominization and of counting time that constitute them, then it is also true that "space as such does not exist independently of cultural techniques of spatial control ... The list is to be extended."58 My proposal for expanding the list is as follows: neither the revolution, nor the revolutionaries, nor the barricades as such exists independently of the media and cultural techniques of the revolutionary through which they are constituted.

The task is thus to write their history as a genealogy of operations of stabilization and destabilization in nineteenth-century Paris. In this respect, barricades and boulevards do not emerge as closed formations in a static opposition (for example, as subversive disorder vs. monarchic/bourgeois order); rather, they become visible as agents themselves in those concrete techniques and operations that first create and determine these relations. Revolutionary cultural techniques of the barricade are - in Paris and elsewhere - nothing more than chains of interrelated negotiations between an "art of street blocking"59 and an "art of the government." ${ }^{60}$ In this way, the "insurgent work" of which Caussidière speaks becomes culturally observable and describable as an "art" of revolutionary change based on specific instructions for action.

57 See Nègre, L'Art du chantier.

58 Bernhard Siegert, "Kulturtechnik," in Einführung in die Kulturwissenschaft, ed. Harun Maye and Leander Scholz (Munich: Fink, 2011), 95-118, here 99.

59 L'illustration: Journal universelle (May 13, 1871): 268.

60 Michel Foucault, "Space, Knowledge, and Power," 240. 
